\title{
Iambic Horror: Shivers and Brokenness in Archilochus and Hipponax
}

\author{
Mario Telò
}

Now, the letter rho, as I was saying, seemed to the name giver a good instrument for the representation of motion.... Through this letter, he imitates motion first of all in the words pॄîे ("to flow") and pon̂ ("flow"), then

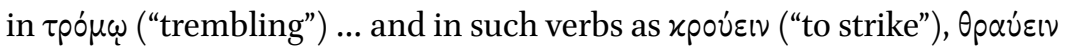
("to crush") ... Өpú $\pi \tau \varepsilon \imath \nu$ ("to break").... He saw, I think, that the tongue in

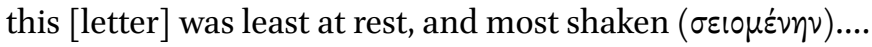

Do you think we were right to say that the rho resembles motion, movement, and harshness $(\sigma x \lambda \eta p o ́ \tau \eta \tau \iota)$ ?

PLAT. Crat. 426d-e, 434c

The Romantic fetishization of feeling, as Gérard Genette has told us, was decisive in shaping the modern notion of lyric as a coherent and inclusive genre. While the obvious mimetic quality of epic and drama made them easy for Plato and Aristotle to categorize, the illusion of non-representational spontaneity created by the speaking "I," The Architext suggests, prevented lyric from attaining autonomous, all-encompassing generic dignity in antiquity. ${ }^{1}$ In order to claim a belated place beside epic and drama, ancient lyric, in the hands of the Romantics, had to be granted full mimetic status; it had to be conceptualized as

* I am very grateful to Meg Foster, Leslie Kurke, and Naomi Weiss for improving this chapter with their suggestions. Special thanks are owed to Leslie for encouraging me to participate in the conference on which this volume is based. Thanks also to all the participants for their illuminating comments, and to Emily Gowers, Mark Griffith, and Alex Press.

1 Genette 1992: 6o-67. 
a "representation of feeling rather than as feeling itself" - to quote the editors of the recent Lyric Theory Reader. ${ }^{2}$

Although this schema and especially the notion of lyric as a unified category, in ancient as well as modern literature, are controversial, Genette's narrative invites us to test how a renewed emphasis on feeling and its transmissionwhat social scientists and increasingly literary scholars call "affect" — may help us reconsider our understanding of Greek lyric forms in terms of genre. Sharing ancient literary criticism's preoccupation with the affective power of literary mimesis, we can try to locate a sense of genre in the ways lyric's representations of feeling achieve sensory immediacy, becoming embodiments and projections of "feeling itself." We can heuristically identify genre with the distinctive energies that a lyric form arguably diffuses to its audiences through the materiality of language - the affective force of recurring imagery or sounds. ${ }^{3}$ Affect theory views emotion as a boundless exchange of feeling, circulating beyond bodily boundaries, blurring the distinction between subject and object, the source or producer and the target or receiver. Feeling, in this perspective, becomes a dispossessed, impersonal, contagious force. ${ }^{4}$ The "sensuous dimension of literary experience, ${ }^{5}$ which the idea of affect helps us conceptualize, can contribute to a lyric text's construction of the frame of reference that governs its reception - precisely what we call genre. ${ }^{6}$ While scholarship on archaic Greek lyric has usually emphasized the pragmatics of genre-how a poetic form communicates, socially and culturally, with an audience through its performative occasion - my emphasis is rather on physiology and psychology. Not just fixing the horizon of expectations through social context, ideology, themes, and style, genre can be viewed as a genuinely aesthetic category, a notional, if problematic, demarcation of the quality of intensities that pass between text and recipients, turning form into bodily and psychic engagement. ${ }^{7}$ Genre can also

2 Jackson and Prins 2014: 12. For the link between genre and mimesis in archaic Greek lyric, see esp. Nagy 1994-1995.

3 On poetic sound as feeling, see, among others, Stewart 2002: 100-101 and Gumbrecht 2012: 4, 13 .

4 Deleuze and Guattari 1987: 257 have observed that "we know nothing about a body until we know what it can do ... what its affects are, how they can or cannot enter into composition with other affects." Seigworth and Gregg 2010: 1 remark that affect "is found in those intensities that pass body to body ..., in those resonances that circulate about [and] between ... bodies" and "sometimes stick to [them]."

5 In the phrase of Altieri 2007.

6 For this definition of genre, see, e.g., Depew and Obbink 20ooa: 6.

7 On embodiment, see Olsen and Estrin (this volume). 
be seen as the material environment created by the unlimited circulation of lyric affect, inside and outside the poetic frame. ${ }^{8}$

Applying this interpretive framework to the case study of one particular Greek lyric genre (or subgenre), iambos, I will explore unfamiliar connections in the extant corpora of Archilochus and Hipponax and in selected expressions of their ancient reception, tying together topographical and bodily images that set up what I call the generic texture of iambos - the tactile experience that this lyric form appears to channel to its audience. The generic affect of Archilochus' and Hipponax's iambos amounts to hairy, bristly, prickly roughness-horror in the Latin sense of the word, with a sensual charge. In their treatment of the "affective fallacy," Wimsatt and Beardsley famously stigmatized aesthetic responses such as the "shiver down the spine" and "tears, prickles, or other physiological symptoms." I will be concerned precisely with how shivers and prickles shape iambos' generic affect in the physical perceptions that its archaic practitioners and their later followers have of it. Iambos' powers of horror emerge from the unexpected textural continuity of disparate objects and sensations - rocky landscapes, shaggy skin, spiny plants, teeth-chattering coldness - as well as from recurring sounds, such as rho, which, in line with the trembling and breaking ascribed to it in Plato's Cratylus, almost functions as a generic phonestheme. ${ }^{10} R h o$ and other broken sounds convert language into sensation, invective discourse into emotional, fleshy investment. Iambic horror, in fact, can produce an edgy feeling of pushing the boundaries of pain and pleasure in an audience that, while touching the iambic texture, identifies with the target of aggression and with the poet himself, whose relationship to his own abjection may be marked by queasy enjoyment as much as aversion." A function of an ever-present and intrinsically ambiguous "you" (both target and audience), this mimetic dynamic realizes the lyric dimension of iambos and enables us to materialize its projected generic identity, to perceive such

8 Affect is what brings out, in Deleuze's words, "the atmospheric quality" of discourse (1994: 24). While affect has been identified with form itself (see Brinkema 2014), in my analysis I maintain a notional distinction between affect as emotional, psychosomatic content and lyric form as the conveyor of such content.

$9 \quad$ Wimsatt and Beardsley 1949: 43, 47.

10 Julia Kristeva's examples of texts with the "powers of horror" include Celine's London Bridge, with its descriptions of "piercing," “quaking," and "shaking”: see Kristeva 1982: 148. By phonestheme, Firth 1964 meant a pairing of phoneme and meaning such as, in English, the consonant cluster $g l-$, which tends to appear in words relating to light and vision.

11 On the reflexivity between the iambic poet and his target, see, among others, Miralles and Pòrtulas 1983, but this reflexivity involves the audience as well. 
an identity as a manifestation of "feeling itself."12 Linda Williams has assimilated the experience of horror films - a "body genre" par excellence- to "a roller-coaster ride of sadomasochistic thrills." ${ }^{13}$ Figuring an audience's material experience of the genre, not just its roughness against satirical targets, the surfaces that we will touch upon here reveal the masochistic side of iambic thrills, teasing us with frissons, jolts, and spasms, titillating sensations of aestheticized abjection that disrupt corporeality yet expand its limits. Iambos' distinctive projection toward a "you," in its double valence of target and audience, produces a poetic frame predicated on a programmatic transgression of that frame (in the etymological sense of "stepping out or beyond" it). ${ }^{14}$ In its formal inclination to step outside of its own discursive frame, iambos is emblematic of lyric affect. As an impulse to push past the frame of the body, the masochistic thrills promised by iambos affectively realize the stepping beyond that is intrinsic to its discursive form.

A journey through the textures of iambos might begin with Archilochus' programmatic description of Thasos, in which topographical and animal imagery figure the generic feel of iambos (fr. 21):

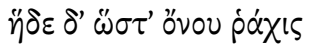

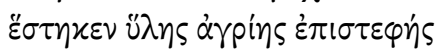

This [island] stands like the spine of a donkey, garlanded with a wild forest

Noting that Archilochus seems to efface Thasos' abundance of fruit trees and

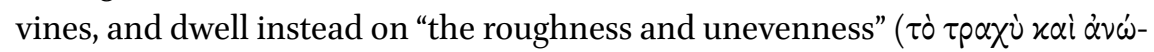
$\mu \alpha \lambda \circ v)$ of the landscape, Plutarch, the fragment's source (De exil. 6o4c), sees this emphasis as satiric "slander" ( $\delta เ \varepsilon \hat{\beta} \beta \lambda \varepsilon)$. The victim of Archilochean aggression, in Plutarch's view, Thasos is itself cast as an aggressor, its Thracian wildness matching the iambographer's verbal roughness, as showcased by the verbal res-

12 According to Culler 1977, 2015: 186-243, the apostrophe (the inscription of a "you" within a poem's discursive framework) is an essential device for creating the impression of temporal presentness, a fundamental dimension of the "lyric event." Waters 2003 has seen the apostrophe as tactile, a marker of lyric's aspiration to direct feeling beyond the closed space of the poem, to establish an affective relation with its audience. Regarding the sensual implications of the overlap between satiric addressee and audience, I have found the analysis of the Priapea offered by Young 2015a particularly illuminating.

13 Williams 1991: 7.

14 As Leslie Kurke points out to me, this iambic "stepping out or beyond" previews, in a sense, the parabasis of Old Comedy. 
onance of Archilochus' simile ( $\dot{\rho} \alpha \dot{\chi} \backslash \varsigma)$, Plutarch's metadescription ( $\tau p \alpha \chi \dot{\jmath} \varsigma$ ), and the place name $(\Theta p \dot{\alpha} x \eta) .{ }^{15}$ Whatever Archilochus might have thought of his second home - the place where his Parian father allegedly founded a colonythe exiled poet found in the island a reflection of iambic $\tau p \alpha \chi \dot{v} \tau \eta \varsigma .{ }^{16}$ Hipponax's birthplace, Ephesus, performs the same self-reflexive function. Its urban topography, as we see in fragment 50.2, includes a place situated "between Rough and

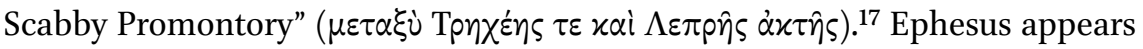
to be an obstacle course through pointed surfaces like the rocks and forests of Thasos, as well as iambos' harmful sounds. In the Archilochean fragment, $\dot{\alpha} \alpha \mathbf{x}$ 's, which causes savage terrain to slip into animal physicality, contains a substantial phonemic portion of $\tau p \alpha \chi \dot{v} s$, an aural reflection of the unity of Thasos' sharp edges and a donkey's bristly hide. ${ }^{18}$ Through this insistent combination of aspirated rho and velar consonants corresponding to Archilochus' and Hipponax's

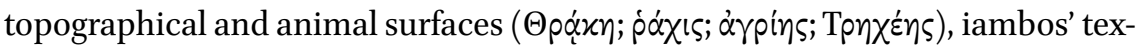
ture, its affect of harshness, thus emerges. In a fragment of Aristophanes, the "hardness" ( $\sigma x \lambda \eta$ pótn $)$ of Aeschylean tragedy is compared to the tough skin of pigs and cows. ${ }^{19}$ Almost a crypt word for $\tau p \alpha \chi ن$ 's, the spine of the Archilochean donkey, isolated at the end of the line, similarly embodies a generic sensation, enabling us to experience, almost physically, the edgy quality of iambos, its character as a locus horridus, its Thracian position—on the fringes of literary pleasure.

The convergence of asinine body, locus horridus, and novelistic texture in Apuleius' Metamorphoses can help us understand how, in the Archilochean fragment, the donkey's skin materializes the iambic persona's double role as an agent of abuse and an abject victim. Some of Apuleius' descriptions of

15 On $\tau p \alpha \chi ن \dot{\varsigma} \varsigma$ as a designation of an angry voice, see, e.g., [Aesch.] $P V$ 311, 1048.

16 On the relation between the persona loquens and Archilochus' autobiography in this fragment, see Bowie 2009: 108-109; for a more skeptical approach, see Owen 2003. The reception of Archilochus takes his association with Thasos as a generic marker, as shown by

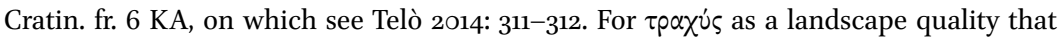
transfers virility to inhabitants in Hdt. 1.71.2, see Purves 2013b: 31-32. On landscape as a reflection of literary-critical categories, see esp. Worman 2015a, 2015b; on "generic topography" in Pindar, see Kurke 2013b: 120.

17 The Ephesian topography alluded to here is discussed by Strab. 14.1.4, the source of the fragment.

18 ' $\mathrm{\alpha} \chi \chi \measuredangle \varsigma$ is almost an anagram of the Latin acris, feminine of acer, a common onomatopoetic designation of satiric roughness: see esp. Gowers 1993: 131-132. In discussing the aesthetics of $\pi \cup x v o ́ t \eta \varsigma$ in Homeric narrative, Purves 2013a: 58 connects the thick bristliness of the boar's back in $\mathrm{Od}$. 19.446 with "the thickly-charged environment" of the scene.

Ar. fr. 663 KA. 
loci horridi-mountains, rocks, torrents, and thickets—are entangled with language used for the donkey's body. ${ }^{20}$ In particular, Lucius' metamorphosis takes place through a thickening of hair, marked by the verb horripilo, into a virtual thicket, and a hardening of skin — both folding the human-turned-animal into the frightful landscape. ${ }^{21}$ Lucius' transformation equips him with the power to kick, but also makes him a slave, by definition subject to beating and flogging. ${ }^{22}$ The donkey's horrid landscape - the spiky rocks and craggy mountain pathscomplements his abusers' sticks and whips. ${ }^{23}$ As Jason König has observed, Apuleius' novel presents "an obsessive and gruesome fascination with the extreme vulnerability of human and asinine bodies to the physicality of landscape." ${ }^{24}$ The landscape, which victimizes the protagonist even after co-opting him, reifies not just the notorious asperity of Apuleius' style, but also his text's narrative texture. ${ }^{25}$ Before the final redemption, the novel's ceaseless obstacles and travails are like rough edges whose abrasions accrue on the bristly skin of the novel's animal protagonist and victim. The horrid terrain of Archilochus' Thasos empathically connects his audience with the target of iambic invective, who is forced to pass through the cutting crags and prickly vegetation of his satire. However, Thasos' donkey-like bristliness also mimetically channels to the audience the downtrodden affect of the satirist, who, besides kicking, is himself a victim of blows, like the Apuleian Lucius.

This iambic abjection concentrated in Thasos also takes a human shape, a grotesque female figure emanating a prickly sensuality. Fragment 22 continues the portrait of Thasos by contrasting the island with the region of Siris-an icon of southern Italian abundance and fertility named after the first wife of King Metapontus: ${ }^{26}$

$20 \quad$ On the locus horridus in Apuleius, see esp. Schiesaro 1993; König 2013.

21 Cf. 3.24, where duratur, which designates the hardening of Lucius' skin, echoes the description of petrified humans in 2.1.

22 For the connection between Lucius' donkey skin and slavery, see Fitzgerald 2000: 100.

23 See 7.17.4.

24 König 2013: 231.

25 Selden 2014: 239-245 has recognized distinctive Afro-Asiatic elements in Apuleius' style, whose harsh twists and turns could be viewed as a reflection of the rugged Libyan landscape. The horrid nature of Apuleius' loci horridi is enhanced by the concentration of moody sound effects, noted by De Biasi 1990: 14-15, including a prevalence of $r$.

26 This is the identification proposed by Athenaeus (12.523d), who cites the fragment. Against the tenuous hypothesis that Archilochus may refer instead to a river in the Propontis called Syros or Sirios, see Moscati Castelnuovo 1989: 43-47. According to $\Sigma$ Dion. Perieg. 461, when Metapontus replaced Siris with another woman, he sent her off into the eponymous region. 


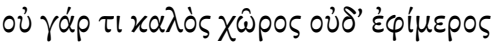

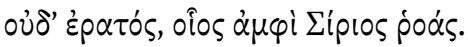

For it is not at all a beautiful, desirable, or lovely land, like the one around Siris' stream.

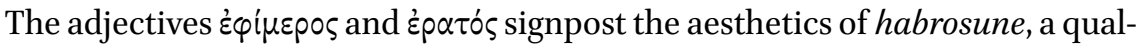
ity proper to erotically charged bodies and loci amoeni but also to the soft poetic texture that several lyric voices, privileging these imagistically interchangeable subjects, claim for themselves. ${ }^{27}$ In Sappho fragment $16 \mathrm{~V}$, Anactoria's "lovely stride" (हैp $\alpha \tau o v ~ . . . \beta \hat{\alpha} \mu \alpha$ ) points to the poem's own soft, rhythmic pace, as Yopie Prins has suggested. ${ }^{28} \mathrm{Alcman}$ indirectly maps the alluring topography of

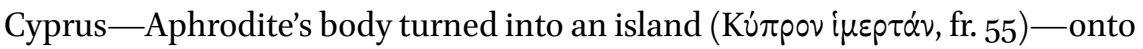

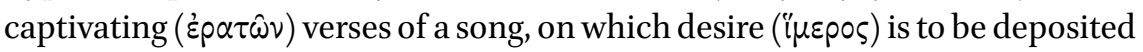
as a quasi-tactile layer (fr. 27). ${ }^{29}$ Archilochus irreverently purports to enter this generic landscape in the last section of the Cologne Epode, where the account of the sexual encounter proceeds through references to a locus amoenus, soft surfaces (of a female body and a cloak), and gentle touching - possibly deceptive flirtations with other lyric genres' sensoria, which are then overturned by the iambic coarseness of the final act. ${ }^{30}$ Against this background, the comparison of Thasos with Siris, a counterpart of Alcman's Cyprus, invites us to view the

27 On the complex materiality of lyric habrosune, see Kurke 1992, 2007: 147-152; on the aesthetics of softness in Sappho and Alcman, expressed by the recurring adjectives $\mu \alpha \lambda \theta \alpha$ xós and $\dot{\alpha} \pi \alpha \lambda$ ós, see also Burnett 1983: 299 and MacLachlan 1993: 63 n. 17. In Sappho, softness is one of the sensory domains where, as Prins 1999: 98 observes, "the language of place shades into the language of the body."

28 See Prins 1999: 128, who presents Anactoria as "a figure fleshed out by the rhythms of Sappho and bodied forth as rhythm itself."

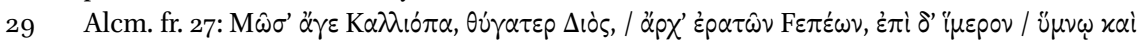

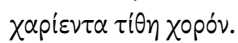

30 Cf. 196a.42-43 $\varepsilon^{\prime} \nu \ddot{\alpha} \nu \theta \varepsilon[\sigma / \nu / \tau \eta \lambda] \varepsilon \theta \dot{\alpha} \varepsilon \sigma \sigma l$ (a phrase that is resonant with Sapph. fr. 2.9-10

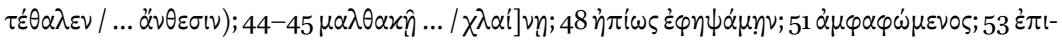

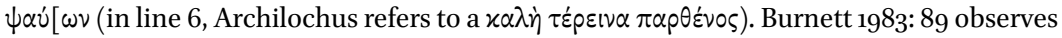
in the poem "an astonishing confluence of abuse with ... sensual detail" - an aspect of its self-consciously "insidious" nature, in the words of Kurke 2000: 71. Even when infiltrating other lyric territories, the iambicist cannot entirely leave aside his innate roughness; conversely, ostensibly soft lyricists represent the violence, the "roughness" of love (see for example, Sappho fr. $3^{1} \mathrm{~V}$ ) and occasionally seem even to be able to assume an iambic guise (see Brown 1984 on Anacreon, and Rosenmeyer 2006 and Martin 2016 on Sappho). Besides the Archilochean poem's well-known engagement with epic seduction scenes (on which see Swift 2015), there is, thus, an intralyric dimension, a self-positioning that tries to negotiate the complex play of difference and similarity at the root of the notion of genre itself. 
former as a female surface - a reading also suggested by the following passage from Semonides' misogynistic tirade (fr. 7.50-54):

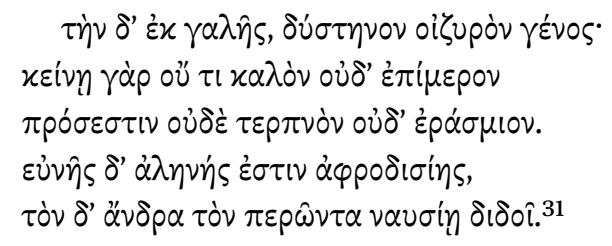

Another woman is from the weasel, a wretched and woeful creature; she has nothing that is beautiful or desirable or pleasant or lovely. But she is mad for the sexual bed, and gives the man who penetrates her to nausea.

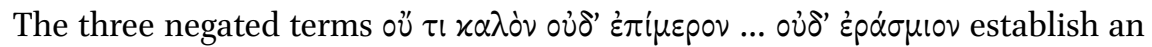
unexpected link between this presumably bristly weasel-woman and Archilochus' donkey-like Thasos, as does the onomatopoetic adjective oi̧upóv, derived from the exclamation of grief ol. Archilochus calls Thasos a "three times

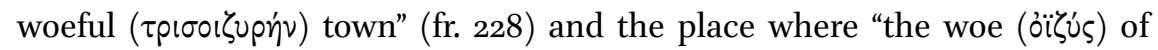
all Greeks has run together" (fr. 102). The textural kinship of the weasel with the Thasian donkey, in turn, alerts us to a possible identification between the Semonidean abuser and his target. In general, the iambicist shares with the weasel a trickster mind and sexual voraciousness; more importantly, in the passage above, Semonides makes his audience experience, even vocalize the sensation he attributes to the female/animal target's lover. ${ }^{32}$ The line that speaks

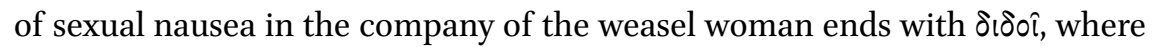
the stress, grammatical and metrical, on the last syllable enacts the affective dynamic, exposing the listener/reader to the sound of the pain (oil) conveyed by oǐupós. It is as though listening or reading allowed one to feel the disagreeable conclusion of an intimate encounter that resembles a ramble through Thasos' craggy landscape. The grammatical structure of the last sentence, with the dative $v \alpha v \sigma i n$ governed by $\delta i \delta \circ \hat{l}$, suggests that this sensory experience is tantamount to intercourse with nausea itself, personified and domineering.

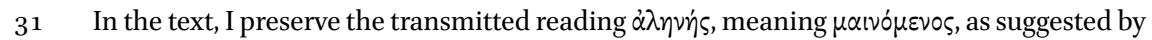

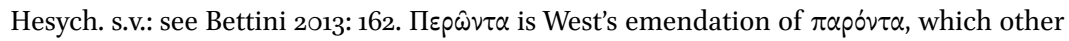
editors retain in the appropriate dialectal form $\pi \alpha p \varepsilon o ́ v \tau \alpha$. Regardless of the text, the line clearly describes sexual intimacy between the weasel-woman and $\tau \dot{\nu} v \alpha \dot{\alpha} \nu \rho \alpha$.

32 On the weasel as a sexually voracious trickster, see Bettini 2013: 162-163, who also points out the animal's foul smell. On "the iambic poet as a trickster," see Miralles and Pòrtulas 1983: 11-5o. 
Conversely, in light of Semonides, Thasos' savage vegetation starts to resemble, as the adjective $\dot{\varepsilon} \pi\left\llcorner\tau \varepsilon \varphi \eta \dot{\zeta}\right.$ suggests, the rough garland specifically of a woman. ${ }^{33}$ The iambicist presents a hairy, uneven, masculine surface as female in lieu of conventional lyric softness-not unlike $\dot{\eta}$ $\nu \bar{\eta} \sigma 0 \varsigma$ itself, which bears the duality of feminine gender in a male form. ${ }^{34}$ Although the iambicist often fantasizes about tender, fragrant female bodies or lovely tresses and may even seem to valorize Siris in comparison with the donkey-(or weasel-)like Thasos, he ends up aestheticizing sensual edginess as generic difference, titillating his audience with coarse textures, perhaps even stimulating a queasy delight. ${ }^{35}$

Bristly Thasos may lurk behind Archilochus' famous contrast of generals, suggesting another connection between iambic landscape and human surfaces. In his First Tarsian Speech, Dio Chrysostom (33.17) cites these lines, which have traditionally been read as an Archilochean intervention on the theme of epic heroism (fr. 114): ${ }^{36}$

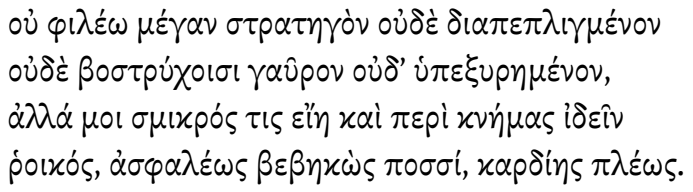

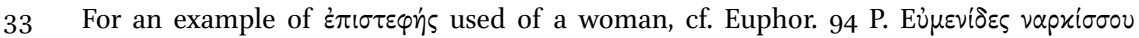

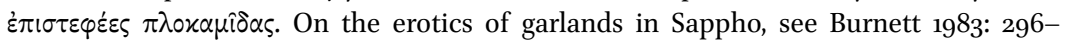
297 .

34 On the transgender dimension of the iambic persona in Horace, see most recently Gowers 2016, who mentions Lamia, a female figure with male genitals, among iambos' mythological ancestors.

35 In fr. 119 Hipponax expresses a desire for a "tender" $\pi \alpha p \theta \varepsilon \dot{v} 0 \varsigma$, as Archilochus does in the Cologne Epode (see n. 30). In frs. 30-31, Archilochus provides other snapshots of fantasized female habrosune, probably looking ahead to a scenario of iambic coarseness (see

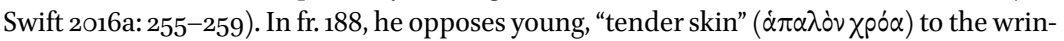
kles of old age, which are imputed to wintry winds. The bodily and natural roughness apparently deplored here is precisely the generic feel of iambos that we are reconstructing (on coldness and shivers, see below). Horace's widely recognized appropriation of the Archilochean wrinkles in Epod. 8.3-4 belongs to a similar stew of miasmic misogyny. Yet, as Richlin 1992: 113 observes, "Horace clearly enjoys ... a thorough stare at ugliness, wallowing in the foulness he creates and rejects." Moreover, the decrepit female bodies so vividly detailed here are "uncomfortably" similar to that of the invective poet himself, as Oliensis 1998: 75 has noted. A generalized preference for the rough, uneven surface and sensation may well transcend gender divisions, as we will see in Archilochus' preference-sexual or otherwise-for the "bent" general over the smooth, shaved one, with his legs apart. Greek archaic iambos offers itself to its audience precisely as an ugly body pushing sensory experience to the edge.

36 See, for example, Toohey 1988. 
I do not love a big general, with legs apart, proud of his curls, and partly shaved. Let me have one who is small, looks bent around the shins, stands firmly on his feet, and is full of heart.

Critics have noted the lack of parallelism in the portraits of the two strategoifor example, the lack of an antonym for i $\pi \varepsilon \xi \nu p \eta \mu \varepsilon v$ vov ("shaved"). Dio himself, in his paraphrase, presents Archilochus' preferred general, "mulish" or "perhaps even donkeylike," in Mark Griffith's words, as "hairy" ( $\delta \alpha \sigma$ $\varsigma)$ on his shins. ${ }^{37}$ Certainly, as Tom Hawkins observes, this added detail, playing on the classic opposition of effeminate smoothness and virile hairiness, fits the moralistic agenda shaping Dio's reperformance of Archilochean iambos in Roman Cilicia. ${ }^{38}$ Going a step further, we might detect in Dio's invocation of Archilochus' preferred general, wrapped in a critique of the unmanliness of the Tarsians, a residue of the original Thasian texture of iambos, which is similarly cast

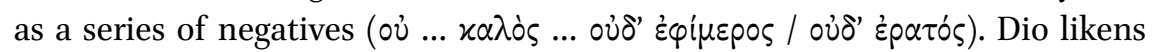
the two generals, one slick and the other hairy, to urban landscapes: the former to an imperial, sumptuous locus amoenus - rivers, baths, fountains, porticoes, and fancy houses; the latter to a small town built "on a rock" ( $\dot{\pi} \pi \mathrm{i}$ $\pi \dot{\varepsilon} \tau p \alpha \varsigma)$. This alignment of hairiness with a rugged landscape recreates Thasos' iambic topography, the "unevenness" that Plutarch had criticized Archilochus for emphasizing - also expressed in the bent, though firmly planted, legs of the preferred general. The Archilochean phrase $\dot{\alpha} \sigma \varphi \alpha \lambda \varepsilon^{\prime} \omega \varsigma \beta \varepsilon \beta \eta x \dot{\omega} \varsigma \pi 0 \sigma \sigma i$ would be apt for the stabilization of the originally floating Delos, for example, which both Pindar and Callimachus anthropomorphize, respectively assigning it "steely

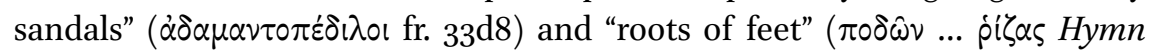
$4 \cdot 54) \cdot{ }^{39}$ The unshakability goes along with the island's rough, rocky geology, unsuitable for cultivation, like Thasos. 40

Discovering reflections of Thasos' rockiness in the asperity of Archilochus' description, we may supplement Dio's moralistic take on the general's shaggy body with an appreciation of its "powers of horror," its scratchy (dis)pleasures. The smoothness of the freshly shaved general is matched by the glossy verbal and rhythmic surface of the first two lines, organized into symmetrical units of syntax and meter joined by polysyndeton and internal echo ( $\sigma \tau \alpha \tau \eta-$

37 Griffith 2006: 314. Some modern critics have tried to insert Dio's $\delta \alpha \sigma \dot{\sigma} \varsigma$ in Archilochus' text: see Pisani 1938.

38 See Hawkins 2014: 206-214.

39 On these two passages, see Nishimura-Jensen 200o: 289-292.

$40 \quad$ As emerges from $\Sigma$ Call. Hymn 4.11a, b, which gloss $\ddot{\alpha} \tau p \circ \pi \circ \varsigma$, said of Delos, as $\dot{\alpha} x i v \eta \tau \circ \varsigma$ xai

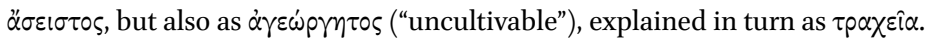




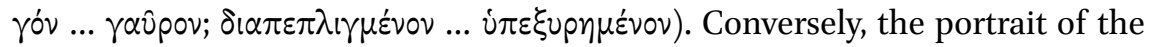
hairy one is a Thasian thicket of qualifiers, unevenly linked (first by $x \alpha i$ and then with asyndeton), disrupting the previous lines' seamless continuity with a sharp enjambment. Closely resembling póxı , the marker of the asinine feel of Archilochus' home, pooxós captures Thasian $\delta \alpha \sigma u ́ t \eta \varsigma$. As an aspirated consonant, rho is, according to ancient grammarians, a quintessentially hairy sound, $\delta \alpha \sigma \dot{v}$ or hispidum. It is the so-called canine letter, which Genette included in his Voyage en Cratylie, following the lead of this passage of Persius (1.107-110):41

\section{Sed quid opus teneras mordaci radere vero auriculas? Vide sis ne maiorum tibi forte limina frigescant: sonat hic de nare canina littera.}

But what is the need of scraping tender little ears with biting truth? See to it that the thresholds of your betters do not, by chance, become cold for you: here the snarl of a doggy rrrr sounds from the nose.

Bundles of rhotic energy, radere and frigescant render satiric invective's scratchiness and the shivers of the abject satirist. ${ }^{42}$ The initial rho of porxo's and $\dot{\rho} \alpha \chi \zeta$ in Archilochus affects both the iambicist and his targets, victims of

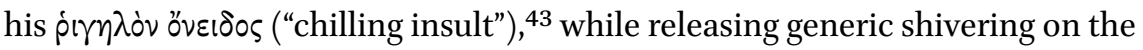
audience. The sequence of aspiration in ṕx $\chi 15$, besides reproducing the feel of asinine skin, may suggest the goosebumps caused by Thracian rigors, while pixvós, an alternative form of poxxós, can, in fact, mean $\pi \varepsilon \varphi p(x \omega \dot{\omega} \varsigma$ ("shriveled with cold"). ${ }^{44}$ Archilochus' celebration of his general's courage and "unshaken" temper is central to Dio's moralistic reading. Still, the texture of poixós, which $\sigma \mu \iota x p o ́ s$ anticipates, hints at a not-so-firm figure who perhaps, like the iambi-

41 Cf. Genette 1995: 37-38. On rho as hispidum, cf. Terent. Maur. GL vi 333, 262 K. In De comp. verb. 14, p. 54. 13 U.-R., Dionysus of Halicarnassus defines rho as the liquid sound that "roughens ( $\tau p \alpha \chi ن \dot{v \varepsilon \varepsilon l) ~ t h e ~ e a r . " ~ T h e ~ c a n i n e ~} r$ is also discussed in Lucil. 377 M., to which Persius alludes. Dionysius' treatment of "rough" sounds has been widely discussed; most recently, Purves forthcoming has called attention to the temporal dimension of such sounds, their effect of slowing down a text. Porter 2010: 371-397 offers an extensive discussion of the aesthetics of another notoriously "harsh" consonant, sigma.

On this passage, see Bramble 1974: 151-152 and esp. Keane 2006: 93. On the shivering Hipponax, see below.

43 This is the characterization of Archilochean iambos that we find in an epigram by Dioscorides $(A P$ 7.351.5-6), spoken in the voice of Lycambes' daughters.

44 Cf. Soph. fr. $1091 \mathrm{R}^{2}$. 
cist, trembles while attacking. The iambic phonestheme rho, which growlingly initiates poixós and $\dot{p} \alpha \dot{\chi} \backslash \varsigma$, feels like an encounter with hispid body parts that slides into shudders, the generic sensation of horror.

Turning our attention to one of Archilochus' widely recognized animal alter egos, we can appreciate other ways in which iambic affect emerges from the friction of scratchy surfaces-a stick, a trap spring, or a fox's tail. Fragments 185-187 relate to the Aesopic tale of the fox who brings down a pompous monkey elected king of the animals. ${ }^{45}$ The fable, deployed to attack a "herald's son" ( $\hat{\omega}$ Knpuxio $\eta$ ), is presented, in fragment 185 , as the message on a leather strip wrapped around a herald's stick-a $\sigma \varkappa v \tau \alpha \dot{\lambda} \eta \eta$ that, like the iambicist, shouts in distress $\left(\dot{\alpha} \chi v \nu \mu \varepsilon^{\prime} \nu \eta\right) .{ }^{46}$ After luring his target into a trap, the fox scornfully points out his fall, from top to bottom (fr. 187):

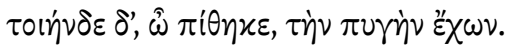

monkey, with a tush like that

As has been observed, $\pi \cup \gamma \eta \dot{v}$ reconfigures $\pi \cup x v o ́ v$, employed in fr. 185 to express the fox's (and satirist's) intellectual primacy ( $\pi \cup x v o v v$ É $\chi 0 v \sigma \alpha$ vóov) ${ }^{47}$ But aside from signaling a mind-body opposition, the intratextual pun may point to a physical contrast-between the monkey's smooth $\pi \cup \gamma \dot{y}$ and the fox's own

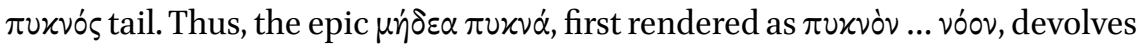
into a bodily extremity, coarse in both its register and materiality. The fox's tail is not just shaggy, but pointed, a stand-in for other sharp vulpine edges-tongue, teeth, claws, ears, snout, and, figuratively, mind. His base self-aggrandizement, then, helps us see the fox, whom Theocritus calls $\delta \alpha \sigma u x \varepsilon p$ xos ("bushy-tailed"), as another bristly animal analogue for Thasos-like the shaggy general, who is similarly positioned against a shamefully smooth adversary. ${ }^{48}$ We can tease out further implications by considering the trap that defeats the monkey (186):

45 On the place of this fable in the Aesopic tradition, see van Dijk 1997: 144-147; on Archilochus' treatment of this fable in relation to his satiric agenda, see esp. Rosen 1988: 17-18; Bowie 2008: 133-136; Steiner 2010: 99-100, 2012b: 19-29, 2014b, and 2016; Pappas 2014.

46 I take $\alpha \chi \chi v \mu \varepsilon \dot{\varepsilon} \eta \eta \sigma x v \tau \dot{\alpha} \lambda \eta$ as a nominative. The classic discussion of the Archilochean $\sigma \times v-$ $\tau \dot{\alpha} \lambda \eta$ is West 1988. On the interpretation of $\alpha \chi \chi v \mu \varepsilon \dot{\varepsilon} \eta \eta$, see Pappas 2014. On the rich imagery of the $\sigma \varkappa v \tau \dot{\alpha} \lambda \eta$ in Pindar's Olympian 6, see Neer and Kurke 2019, ch. 8.

47 See Pappas 2014: 28.

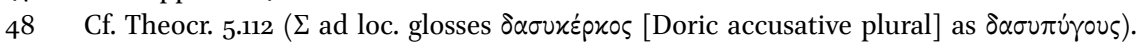
The connection of the monkey with the "shaved" (i $\pi \varepsilon \xi \cup p \eta \mu \varepsilon v o v)$ general is perhaps reinforced by Aristophanes' appropriation of the Archilochean line in Ach. 119-120, in which an ambassador is addressed as "smooth-assed," a "monkey, with a beard like that": $\pi \rho \omega x \tau$ òv 


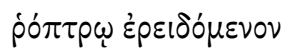

pressing on the trap spring

A piece of bent wood that sets a trap in motion when touched, the pó $\pi \tau p o v$ brings to mind the crooked legs ascribed to the poxxós Archilochean general. ${ }^{49}$ The semantic connection corresponds with the textural consistency of the two words, which both incorporate the letter rho ( $\dot{\rho} \circ$ ) itself, making palpable the contact of some body-monkey, satiric target, or listener/reader-with the rough and curved surface of iambos. In this moment of contact, triggering iambic horror, the ṕó $\tau$ pov, in a way, realizes the generic affect of the similarly curved fox's tail and the $\sigma x v \tau \alpha \dot{\lambda} \lambda \eta$, the doleful stick that resembles the shaggy general's firmly planted legs.

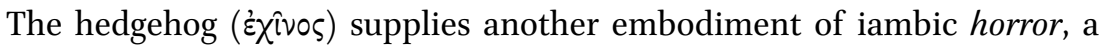
further example of how this generic feel arises from animals' bodies and a corresponding rough sound. The apparent confrontation of fox and hedgehog in fragment 201 has caused much disagreement over which of the two has a stronger claim as an authorial alter ego. ${ }^{50}$ Like the fox, the "rough hedgehog"

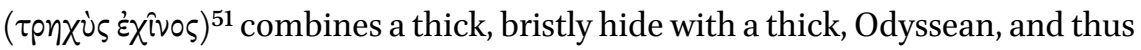
Archilochean, mind; ${ }^{2}$ its spiky surface provides another bodily surrogate of Thasos' topography. ${ }^{53}$ What modern interpreters see as a problem - the apt-

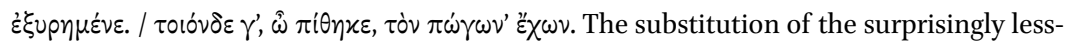
vulgar $\pi \dot{\omega} \gamma \omega \nu^{\prime}$ for $\pi \cup \gamma \eta \dot{v}$, referring here precisely to the lack of a beard, may be informed by the earlier contrast between the monkey's smoothness and the beard-like shagginess of the fox's tail. A self-aggrandizing allusion to vulpine bristliness may also be the point of one of the fragments that map the fable of the vixen and the eagle onto Archilochus' dispute with Lycambes. In fr. 178, the vixen is probably warning the hubristic eagle, whiterumped according to ancient interpreters, that punishment awaits him: $\mu \eta \dot{\gamma} \tau \varepsilon v \mu \varepsilon \lambda \alpha \mu \pi \dot{\gamma} \gamma o v$

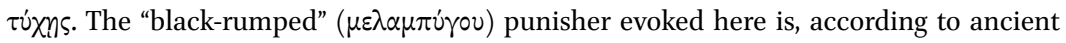
and modern critics, a different type of eagle, proverbially braver than the vixen's enemy and an agent of Zeus himself. If we consider that Luc. Pseudol. 32 connects $\mu \varepsilon \lambda \alpha \dot{\alpha} \mu \tau \gamma \circ \varsigma$ with $\delta \alpha \sigma \dot{\varsigma}$, thus interpreting the epithet as "hairy-tailed," it becomes attractive to think that the "black-rumped" punisher may well be the "hairy-tailed" vixen herself.

49 The source of the fragment (Et. Mag. 715.44) glosses pó $\tau$ tpov as "the bent piece of wood in a trap."

50 For an account of the various positions, see Corrêa 2001: $85^{-89}$, who reacts against the prevailing identification of the Archilochean persona with the hedgehog; see also Bowra 1940 and, most recently, Swift 2019: 386.

51 Opp. Hal. 2.36o.

52 On the Odyssean Archilochus, see esp. Seidensticker 1978. As Meg Foster points out to me, in $O d .13 .242$ Ithaca is described as $\tau p \eta \chi \varepsilon i \alpha$.

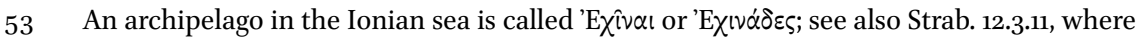


ness of both animals as iambic stand-ins - may be precisely the point of the poem, which could be considered a varied display of generic $\tau p \alpha \chi v^{\prime} \tau \varsigma$ or a dramatization of iambos' boundary-crossing between aggressor and target. ${ }^{54}$

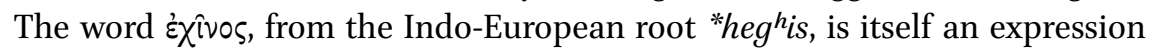
of $\delta \alpha \sigma i \tau \eta$ in the sense of "aspiration," the letter $\chi$ capturing the sensation of the animal's spines-but there is an additional relation with the idea of aspiration as iambic. In the fragment mentioned above, the hedgehog is said to know "one big thing" ( $\varepsilon \nu \mu \varepsilon \gamma \gamma \alpha$ ) while the fox knows many $(\pi \circ \lambda \lambda \dot{\alpha})$, an echo of fragment 126, where the poet, too, professes to know "one big thing" ( $\tilde{\varepsilon} \nu \delta$ ' $\dot{\varepsilon} \pi i \sigma \tau \alpha \mu \alpha \iota \mu \varepsilon^{\prime} \gamma \alpha$ ), how to repay attackers with harm. Whenever the hedgehog feels under attack, it rolls itself up into a ball—in Pliny's description, folding together multiple bodily parts into one. ${ }^{55}$ With the posture that enables the hedgehog's spiky (passive) aggression, it not only knows one thing but becomes one thing ( $\tilde{\varepsilon} v)$, and thus a prickly reflection of the sound of the word, which, like the rolling rho, sends forth an iambic intensity that threatens to scratch and tear the iambicist's enemies but is inevitably felt also on his audience's skin. ${ }^{56}$

This double directionality of iambic feeling has implications for some of Hipponax's poems and their ancient reception. The powers of horror ostensibly mobilized against targets or the self-abusing iambicist appear to impinge on the readers of the Hipponactean corpus. We will see how iambos' sadomasochistic power, its ability to stimulate an audience's desire to push roughly against the human body's limits, contributes to creating a persistent sense of itself as a genre.

The pharmakos fragments, with their imagistic and phonic display of beating and flogging, seem to have shaped ancient readers' perception of the feel of Hipponactean iambos, of its affective legacy. Tzetzes, the main source of

Sinope is said to be inaccessible "because of the prickly ( $\left.\chi^{\prime} \chi v \omega \dot{\delta} \eta\right)$ surface of the rock." In Archil. fr. 190 we find the adjective $\delta v \sigma \pi \alpha i \pi \alpha \lambda \circ \varsigma$, a synonym of $\tau \rho \alpha \chi \dot{\nu}^{\prime} \varsigma$ and $\alpha \nu \omega \dot{\omega} \mu \alpha \lambda \circ \varsigma$,

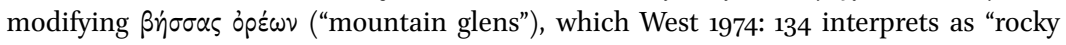
glens ... of the woman's body." This adjective refers to the hedgehog's skin in Opp. Hal. 2.369.

54 Payne 2010: $3^{0-31}$ is an exception, regarding the alleged problem as an expression of the shifting complexity of Archilochus' animal alignments.

55 Plin. NH 8.133 ubi vero sensere venantem, contracto ore pedibusque ac parti omne inferiore ... convolvuntur in formam pilae, ne quid comprehendi possit praeter aculeos.

$5^{6}$ In Hor. Ep. 5.27-28 the bristly hair of an iambic witch, Sagana, is compared to the hedgehog's spiny skin: horret capillis ut marinus asperis / echinus aut currens aper. In these lines, the echinus, probably appropriated from the Archilochean fable, becomes an objective correlative of sonic roughness amid a host of $r$ 's, including the geminated $r$ 's of horret and currens. 
the pharmakos cycle, informs us that the ritual included the use of squills, wild fig branches, and "other wild plants" ( $\ddot{\alpha} \lambda$ oเ $\tau \hat{\omega} \nu \dot{\alpha} \gamma p i \omega \nu$ ) against the scapegoat (Chil. 5.736). We find a glimpse of this practice and its effects in two short fragments, where an iambic victim or the iambographer himself may lie behind the beaten pharmakos - the uncertainty reflects iambos' distinctively mimetic violence (frs. 6,10$): 57$

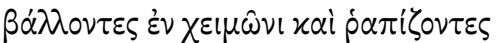

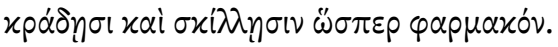

In the winter, hitting and flogging [him] with fig branches and onions like a scapegoat.

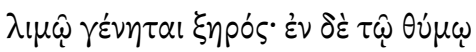

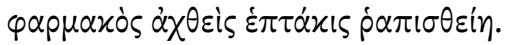

In order for him to become withered with starvation; and having been led off, a scapegoat, may he be flogged seven times on his penis.

With its rhotic force, the verb $\rho \alpha \pi i \zeta \omega$ materializes flogging as an aspirated vibration, which, in the first fragment, is prolonged and intensified through the initial sounds of the word for fig branches, $x p \alpha ́ \delta \eta \sigma$. Here the programmatic force of this painful vibration is underscored by the word's occurrence at the end of the line - the point where a rupture occurs, which is suggestive of the bodily laceration caused by flogging: the marked breaking of the rhythmic flow caused by the choliambic meter. ${ }^{58}$ In the second fragment, $\rho \alpha \pi i \sigma \theta \varepsilon i \eta$ — the culmination of a sequence of aspirated sounds ( $\theta \dot{v} \mu \omega, \varphi \alpha p \mu \alpha x o ́ s, \alpha \dot{\alpha} \theta \varepsilon i \varsigma)$-intimates

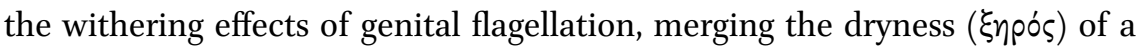
starving mouth with the dryness of impotence, a typical iambic punishment. ${ }^{59}$

57 See Miralles and Pòrtulas 1988: 136.

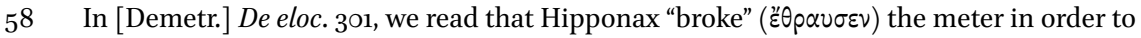
slander his enemies ( $\theta p \alpha v$ w is another onomatopoetic verb cited by Plato in Cratylus: see the epigraph of this chapter). West 1974: 30 refers to the choliamb as "a deliberate crashing incorrectness": see also Boedeker 2016a: 58 . A more extreme form of the meter, with a concentration of long syllables before the final spondee, was referred to in antiquity as

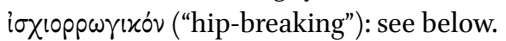

59 In fr. 84.21, $\rho$ '] ب̣ఠóv ("wrinkled"), describing a flaccid penis during intercourse, looks back

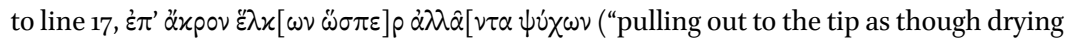

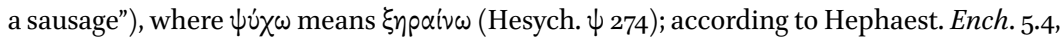
as a result of the spondaic foot that precedes $\psi \dot{v} \chi \omega \nu$, the line becomes "rougher" ( $\tau \rho \alpha \chi v^{\prime}-$ 
This iambic violence is in the background of a Hellenistic epigram by Alcaeus of Messene $\left(A P 7.536=H E 7_{7} 6-81\right)$, where Hipponax's tomb site, covered with brambles and prickly pears, resembles Thasos, Archilochus' locus horridus: 60

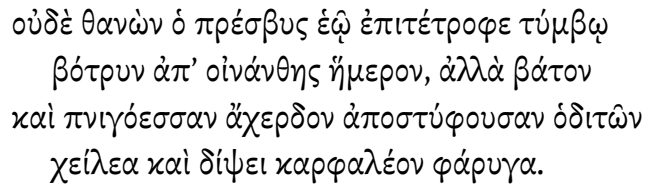

And not even in death does the old man rear upon his tomb a cultivated grape cluster from a tender vine, but a bramble bush and a choking wild pear that constricts travelers' lips and throats, withered with thirst.

The passers-by - images of future readers of Hipponax - are in the same physical condition as the scapegoat, as they approach the iambic thicket with throats

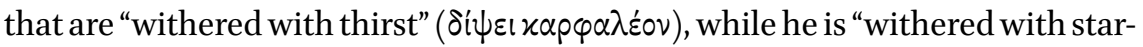

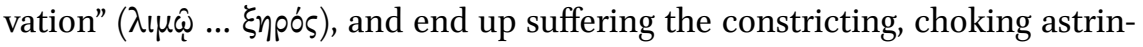
gency of the prickly pear ( $\alpha \chi \chi \varepsilon p \delta \circ \varsigma$ ) — not just a variant of the plants employed in the ritual, but also a "transgender" female like Thasos ( $\pi v v \gamma o ́ \varepsilon \sigma \sigma \alpha \nu$ a $\chi \varepsilon \rho \delta \circ \nu)$

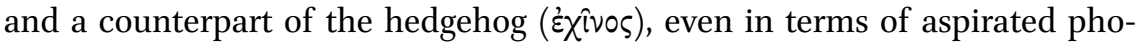
netics. ${ }^{61}$ The verb used to describe the effect of the wild pear, $\dot{\alpha} \pi \circ \sigma \tau \dot{v} \varphi \omega$, strikingly resembles the rare Archilochean verb $\dot{\alpha} \pi \circ \sigma \tau u \pi \dot{\alpha} \zeta \omega$, "to drive away with a stick"62 — as though the blows of a wooden stick, as on the scapegoat's genitals, related in some way to a rough oral sensation, the same constriction of the lips that would be caused by the shift in pronunciation from $\pi$ to $\varphi \cdot{ }^{63}$ The

$\tau \varepsilon p \circ v)$, an effect enhanced by the sequence of $p s i$ and $c h i$. The representation of a genital

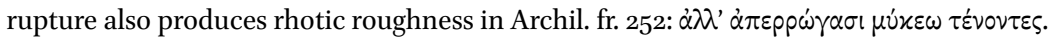

6o For a general discussion of the Hellenistic epigrams on Archilochus and Hipponax, see Rosen 2007.

61 In Hor. Epod. 14.4, we find the phrase arente fauce in a context that emphasizes sexual and poetic impotence (see Oliensis 1998: 89-91), perhaps refashioning the Hipponactean nexus of dryness in the genitals and throat. The hissing viper that we see in Hippon. fr. 79.11

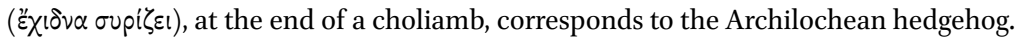

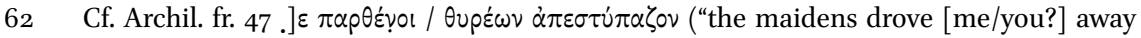
from the doors with cudgels"). The source of the fragment glosses $\dot{\alpha} \pi \circ \sigma \tau \cup \pi \dot{\alpha} \zeta \varepsilon \varepsilon \nu$ as $\sigma \tau \dot{\tau} \pi \varepsilon$ । $\pi \alpha i \varepsilon i \nu$ and $\xi \cup \lambda \circ$ x० $\pi \varepsilon i v$.

63 The epigram's correlative oن่ $\delta \dot{\varepsilon}$... $\dot{\alpha} \lambda \lambda \dot{\alpha}$ recalls the priamels of Archilochus' island and general fragments, the resemblance to the latter reinforced by ßótpus (line 2), which is cognate

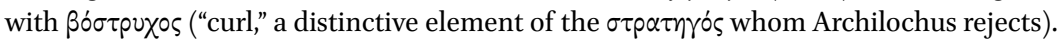
In Callimachus' Iamb. 4, based on a botanical fable, Hipponax is allegorized as thorny flora

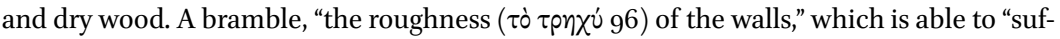


articulatory strain imposed on the reader mimics the violence of the text, as in Hipponax fragment 22, where a representation of torture entails the jugular spasm of a tight, virtually unpronounceable sequence of $x i$ 's: $\tau \dot{\eta} v$ piv $2 \alpha$ xai $\tau \dot{\eta} \nu \mu \dot{v} \xi \alpha \nu \dot{\xi} \xi \alpha \rho \dot{\alpha} \xi \alpha \sigma \alpha$ ("shattering the nose and the mucus"). ${ }^{64}$ The travails of the pharmakos are deeply implicated in Hipponactean readers' iambic experience, modeling the material feel of the genre's contact with its audiences across space and time. The verb $\rho \alpha \pi i \zeta \omega$ appears again at the end of a choliambic line in a rather obscure fragment (fr. 40), in which a mysterious speaker begs Athena to stop his master from flogging him: $x \alpha i$ $\mu \varepsilon \delta \varepsilon \sigma \pi \dot{\sigma} \tau \varepsilon \omega \beta \varepsilon \beta \beta \rho \hat{v} / \lambda \alpha \chi \delta^{\prime} v \tau \alpha \lambda i \sigma \sigma o \mu \alpha i \sigma \varepsilon$ $\mu \eta \dot{\eta} \rho \alpha \pi i \zeta \varepsilon \sigma \theta \alpha \mathrm{l}$ ("since I have been allotted a crazy master, I beg you that I not be flogged"). Through the rhotic force of the verb $\rho \alpha \pi i \zeta \omega$, the prayer actualizes the flagellation it seeks to avert, displacing it phonically onto readers, pharmakoslike victims of iambos' powers of horror.

The mismatch between the iambicist's request for mercy and its effects within and outside the lyric frame is evident in Hipponax's self-presentation as a shivering beggar, which as we will see, looms large in iambos' generic legacy as an affective experience. Hipponax's shivering image emerges in the following addresses to Hermes - first a prayer for help and then a reproach (32 and 34):

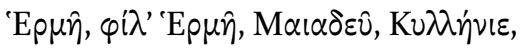

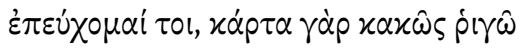
xai $\beta \alpha \mu \beta \alpha \lambda \dot{\zeta} \zeta \omega$...

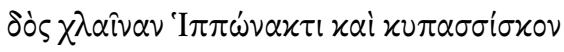

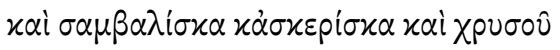

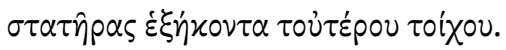

Hermes, dear Hermes, son of Maia, Cyllenian, I entreat you, for I am shivering fiercely, badly, and my teeth are chattering ... give Hipponax a cloak

focate," is one of two alter egos of the Hipponactean persona: see D'Alessio 1996: 17-18. From the Diegesis we know that the bramble stands for the addressee of the poem, the son of Charitades (X $\alpha \rho \imath \alpha \dot{\delta} \delta \omega)$ from Thrace. This identification with a Thracian, whose name

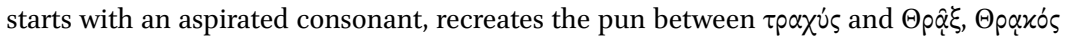
that we found in Archilochus' island fragment. The other iambic alter ego, a "sun-struck" olive tree, which recalls the wooden stick used in the pharmakos ritual and the withered pharmakos himself, declares: "I do not mutter ( $\gamma p u ́ \zeta \omega)$ anything harsh against you" (6o61 - circulating, notwithstanding the negation, the harsh energy of $\gamma p u ́ \zeta \omega$, at the end of the choliamb.

64 West 1974: 143 interprets $\tau \dot{\eta} \nu \hat{\rho} \hat{\imath} \nu \alpha$ and $\tau \dot{\eta} \nu \mu \dot{v} \xi \alpha \nu$ as metaphors for the male sexual organ, but see the reservations of Degani 1983: 43 . 
and a little tunic and little sandals and little felt shoes, and 6o gold staters from the other side of the wall.

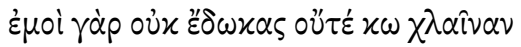

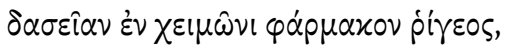

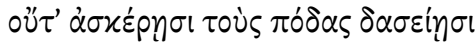 \\ हैx
}

For you haven't given me a shaggy cloak yet as a remedy against cold in winter, nor did you cover my feet in shaggy felt shoes, so that chilblains might not break for me.

Although as a modifier of $\chi \lambda \alpha i v \alpha \nu$ and $\dot{\alpha} \sigma \dot{\varepsilon} p \eta \sigma \mathrm{l}$ in the second fragment, $\delta \alpha \sigma \dot{\nu} \varsigma$ suggests, according to commentators, a protective, healing "thickness" for the shivering speaker, its technical meaning of "aspirated" alerts us to the possibility that Hipponax may, on some level, be looking to augment his shivers and horror - the physiological analogs of phonetic aspiration, as we have seen. ${ }^{65}$ Though the grammatical sense of the adjective postdates Hipponax, $\delta \alpha \sigma u s$ (chosen instead of $\pi \cup x v o ́ s$, the modifier of $\chi \lambda \alpha i v \alpha$ in the Odyssey) indicates a "shaggy" version of a customarily "soft" cloak-something between the conventional urbane garment and an animal skin. ${ }^{66}$ The $\chi \lambda \alpha i v \alpha \delta \alpha \sigma \varepsilon i \alpha$ that the iambicist wishes for might thus be a pharmakon in the full, contradictory sense-a Derridean drug that is not "simply beneficial" but "can worsen the ill instead of remedy[ing] it." ${ }^{\prime 7}$ The prayer and the reproach themselves, while pleading for relief from cold, supply a pharmakon to the audience, engendering shudders through the harsh sibilant and velar sounds of $x v \pi \alpha \sigma \sigma i \sigma x \circ v, \sigma \alpha \mu \beta \alpha \lambda i \sigma x \alpha$, and

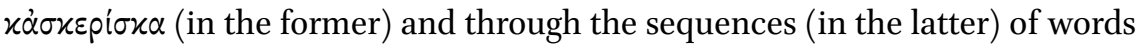

65 On the therapeutic materiality of the $\chi \lambda \alpha \hat{\imath} \nu \alpha$, see Telò 2016 .

66 See Hom. Od. 14.521, 529. The $\chi \lambda \alpha$ iv $\alpha$ requested by Hipponax is usually identified with the typical prize at the Hermaia, the athletic games of Pellene: see Degani 1971: 103. This textile is qualified as soft in Pind. Nem. 10.44-45; see also Archil. fr. 196a.44-45 (see in n. 23). In asking for a "shaggy" $\chi \lambda \alpha i v \alpha$, perhaps Hipponax is playing with his audience's textural expectations and imagining something vaguely similar to the $\chi \imath \tau \dot{\omega} \nu \delta \alpha \sigma u$ s listed as the costume of satyrs in Poll. 4.118-although, as Mark Griffith points out to me, there is countervailing imagery in satyr drama of the creatures' smooth bodies and bald heads that goes along with their tendency to settle back into infantile pleasure taking and comfort seeking.

67 See Derrida 1981: 97, 99, in which he refers to the discussion of relieving an itch in Plato's Philebus as "a painful pleasure, linked as much to the malady as to its treatment" and thus "a pharmakon in itself." See also Peponi 2002: 145-155 and 2012: 116-117. 


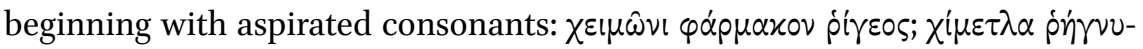
$\tau \alpha$. In particular, píros, which, together with $\dot{p} \gamma \hat{\omega}$ in the prayer, brings us back to frigescunt in Persius' discussion of the canine $r$, has a quasi-programmatic force. We find it, arguably, in encrypted form in fragment 54 as xpir that seems to conflate an owl's shriek with the teeth-chattering chills it pro-

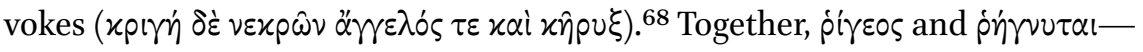
both located where the choliamb breaks - capture the rough iambic energy of Hipponax's poem, a request for a pharmakon that is itself capable of extending the pharmakos-like sensations it apparently seeks to suppress.

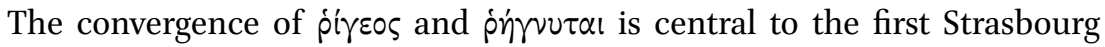
epode (fr. 115), attributed by most scholars to Hipponax. Here all the elements of the generic texture we have sampled so far congeal around the velar and rhotic sounds in $\ddot{x} x$ pos (Latin acer, related to $\alpha x i \varsigma$ "pointed object"), creating a sense of lyric materiality, scratchy and shuddering intensities that cut across thematic and imagistic boundaries:

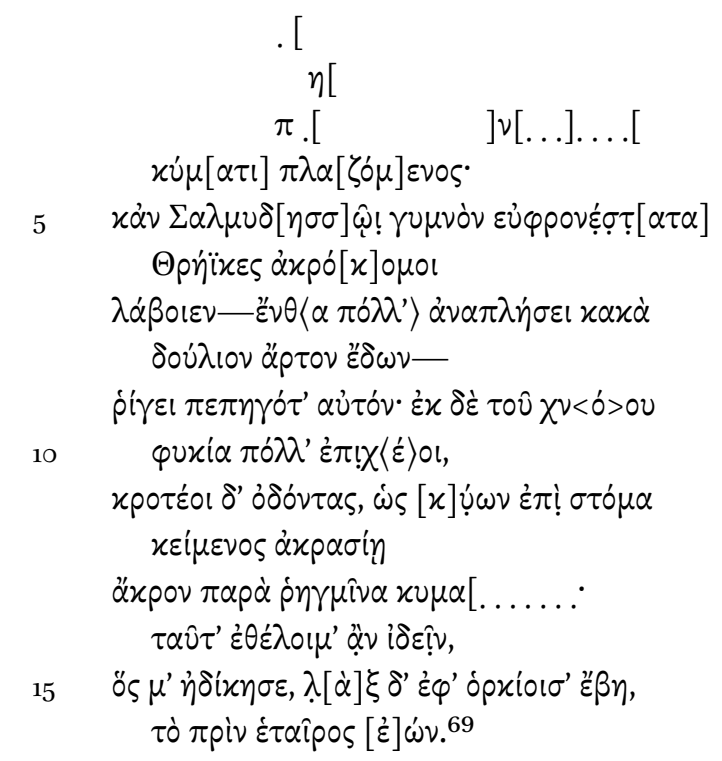

68 See Degani 1982: 257 for the distinction between xpir by $\Sigma$ Ar. $A v$. 1521 as "the shrill produced by the teeth of the dead." This dental sound is similar to the chattering teeth described by $\beta \alpha \mu \beta \alpha \lambda \nu^{\prime} \zeta \omega$ in Hipponax's prayer to Hermes. In Hor. Ep. 5 a strix, a screech owl, with a name phonically reminiscent of $x p i \gamma \eta$, appears in a packed catalogue of the iambic images and sounds we have discussed: trementi ... ore (11); Thracum (14); horret capillis ... asperis / echinus (27-28), on which see n. 56 .

69 The text here follows Degani 1983. 


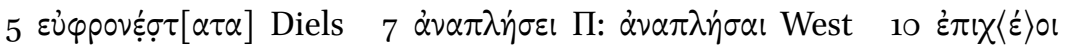
Masson: $\dot{\varepsilon} \pi \dot{\varepsilon} \chi 0 ।$ West

... struck by the waves. And at Salmydessus may Thracians with hair standing up on end most merrily take him while he's naked - there he will have a full share of many evils, eating slavish bread-stiffened from cold. And out of the foam, may he shed much seaweed and may his teeth chatter as he lies face down, dog-like, at the very breaking of the wave, depleted.... I would wish to see these things [happen to the one] who wronged me and trod his oaths underfoot, though formerly a comrade.

Standing on end and making the sea shudder, the waves that will crash on the curse victim express the same material horror as the hair of the $\dot{\alpha} x \rho \dot{0}[\varkappa] \circ \mu \mathrm{ol}$ Thracians - inhabitants of the cold land where Hipponax's enemy will be shipwrecked, near Archilochus' Thasos. ${ }^{70}$ 'Axpóxopor indicates upright hair, similar to bristly, trembling stalks or a lion's shaggy mane-perhaps also sexual arousal, an impression reinforced by the nakedness and proneness of the victim. ${ }^{71}$ The image converges with another hint of iambic texture: the castaway's emergence from the sea, "shedding" ( $\dot{\varepsilon} \pi \backslash \chi\langle\dot{\varepsilon}\rangle / \iota)$ a salty crust of seaweed (9-10), a kind of marine fur comparable to a fox's coat or a $\delta \alpha \sigma \varepsilon \hat{i} \alpha \chi \lambda \alpha i v \alpha .{ }^{72}$ The phrase

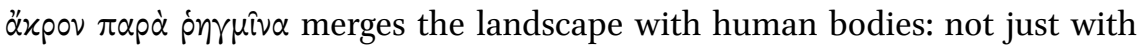

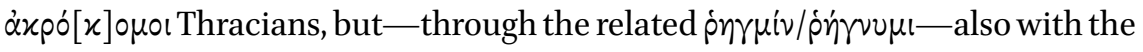
shipwrecked man's skin, beaten, like Odysseus', by waves and "broken," like Hipponax's, by shivers. ${ }^{73}$ Hipponax's own symptoms, epitomized, as we have seen,

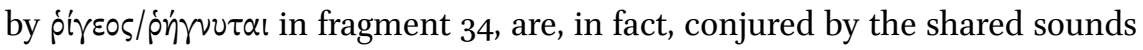

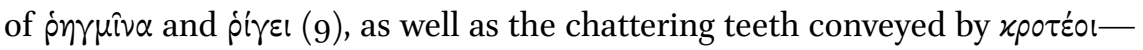
an onomatopoetic verb that incorporates $\ddot{\alpha} x p o s$. The scratchy sounds ( $x$ and $\rho$ )

70 In Il. 4.424-426 a simile presents a wave that "rises to a crest," breaks on the shore ( $\chi \dot{\varepsilon} \rho \sigma \omega$

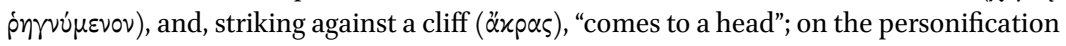
of these waves, which "get their crests up," see Martin 1997:154-156. In Hor. Epod. 10, whose intertextual debt to Hipponax's poem is widely acknowledged, the vehicle of iambic retaliation is "rough waves" (horridis ... fluctibus 3-4); see also Epod. 2.6 and 13.1-3. I owe these references to Emily Gowers.

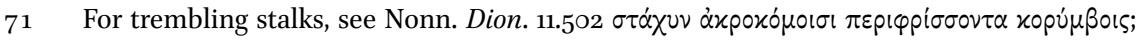

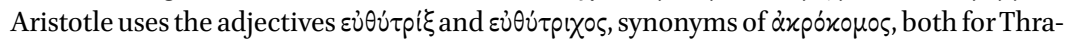
cians and lions: see $G A 782 b_{34}$ and $H A 629 b_{35}$.

72 On the interpretation of $\dot{\varepsilon} \pi \mathrm{\chi} \chi\langle\dot{\varepsilon}\rangle 0 \mathrm{l}$, see Nicolosi 2007: 68-69 and Swift 2019, 427.

73 Odysseus' shipwreck is the main subtext of Hipponax's description. The iambic target's

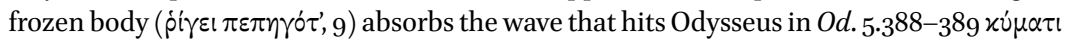

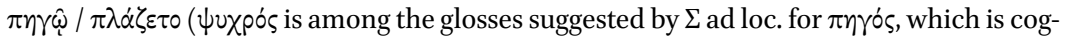
nate with $\pi \dot{\eta} \gamma v u \mu)$. 
of this word, whose Latin counterpart, acer, is used by Horace to describe Hip-

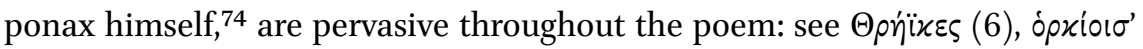
(15), and $\dot{\alpha} x p \alpha \sigma i n$ — which the line break separates from $\ddot{\alpha} x p o v(12-13) .{ }^{75}$ Denoting the weariness of Hipponax's enemy, $\dot{\alpha} x \rho \tilde{\alpha} \sigma i \alpha$ puns on $\dot{\alpha} x p \bar{\alpha} \sigma i \alpha$, a synonym of $\alpha \nu \omega \mu \alpha \lambda i \alpha$, meaning "unevenness," a feature of the iambographer's shaking skin or, as we have previously seen, of Archilochus' Thracian island. ${ }^{76}$ While delivering his curse and vocalizing the sounds that spread its harming power, the poet/performer (re-)experiences his own iambic pathology, eliding again the distance between aggressor and victim. It is as though the somatic horror, the vibrations of Hipponax's body, were directed outward, exposing the listeners/readers to a quasi-physical force similar to the waves' flogging the target $\left(\pi \lambda \alpha\left[\zeta \delta^{\prime} \mu\right] \varepsilon v \circ \varsigma, 4\right)$, to incessant blows of barbed plants on the pharmakos' genitals, or to the prick of pointed objects. ${ }^{77}$

We can see the diachronic reach of Hipponax's shudders in a passage of Plutarch, where a hypocritical Stoic who vaunts his autarkeia is seen at people's doors invoking the iambographer: "Give Hipponax a cloak, for I'm shivering

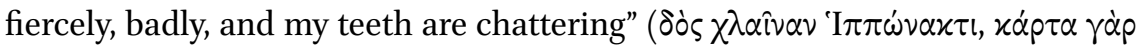

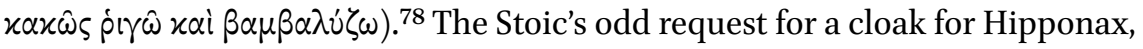
rather than himself, is not simply a matter of theatrical impersonation. ${ }^{79}$ The pompous philosopher's formulation suggests that his hypothermia depends on Hipponax's chills — as though they have been transmitted by contagion. Far from indicating citational "confusion" or an attempt to involve interlocutors and audience in a decoding game, the inversion of the original Hipponactean order- "I'm shivering fiercely, badly, and my teeth are chattering" followed by "give Hipponax a cloak" - may underline this transmissibility: "give Hipponax a cloak because I'm shivering fiercely, badly, and $m y$ teeth are chattering." ${ }^{\prime 80}$ In another Hellenistic epigram warning passersby about the dangers of Hip-

74 Hor. Epod.6.14.

75 On the phonic symbolism of $c r$ as indicating "brokenness" in English, see Genette 1995: 37.

76 Cf. Hesych. $\alpha 2543 \dot{\alpha} x p \alpha \sigma i \alpha \varsigma \cdot \dot{\alpha} \nu \omega \mu \alpha \lambda i \alpha \varsigma . \pi \alpha \rho \dot{\alpha} \tau \dot{o} \mu \dot{\eta} \sigma 0 \gamma x \varepsilon x p \hat{\sigma} \sigma \theta \alpha \mathrm{l}$.

77 On the equivalence between $\pi \lambda \dot{\alpha} \zeta \omega$ and $\pi \lambda \dot{\eta} \tau \tau \omega$, see Nicolosi 2007: 43-44. Commenting on Epod. 10.3-4, which translates the beginning of Hipponax's poem (see n. 70), Oliensis 1998: $92 \mathrm{n}$. 70 suggests that the resemblance between verberes and verba brings together Horace's own "tongue-lashing" and the lashing of wind and waves. On whipping produced by sound in Catullus' iambics, see esp. Young 2015b: 69-70. For a parallel outside classical literature, cf. Prins 2013: 106-108, where she observes that in A.J. Swinburne's poem On the Flogging Block, "the beating of the body is performed in the beat of the poem."

78 Plut. Stoic. Parad. 6.1058d.

79 Cf. Hawkins 2014: 216-219, who sees in the Stoic's impersonation of Hipponax a dramatization of the iambographer's own programmatic assumption of a mask.

8o In the edition of West the adverb confuse introduces the Plutarch passage as a testimo- 
ponax's final resting place $(A P 7.405=G P 2861-2866)$, including the poet-as-

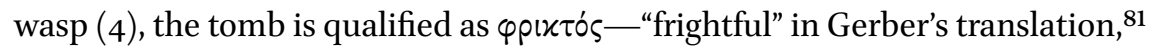
but also, more specifically, "making one's skin shiver." ${ }^{82}$ Like this tomb, Hipponax's poem perpetuates a generic tradition through affect - that is to say, by converting the poet's own staged abjection, his shivers and shudders materialized by formal $\delta \alpha \sigma u$ ins, into a pharmakon for readers-as-targets.

A comparable dynamic of generic affect is observable in one of Catullus' iambic experiments, in which the poet feels on his own skin and spreads Hipponactean shivers, closely aligning them with their pharmakon. In poem 44, written in choliambics, Catullus oddly addresses his own farm (o funde noster, 1), thanking it (as though it were a god) for helping him overcome a recent illness - a cough, whose origins and consequences are detailed in these lines:

nam, Sestianus dum volo esse conviva, orationem in Antium petitorem plenam veneni et pestilentiae legi. hic me gravedo frigida et frequens tussis quassavit usque, dum in tuum sinum fugi, et me recuravi otioque et urtica. quare refectus maximas tibi grates ago, meum quod non es ulta peccatum. nec deprecor iam, si nefaria scripta Sesti recepso, quin gravedinem et tussim non mihi, sed ipsi Sestio ferat frigus, qui tunc vocat me, cum malum librum legi.

For since I wished to be Sestius' dinner guest, I read his oration against the candidate Antius, full of poison and plague. At that point, a chilling head cold and a constant cough shook me, until finally I fled to your bosom, and cured myself with leisure and nettle. Therefore, restored, I thank you enormously because you did not punish my mistake. Now, if I ever shall have accepted again Sestius' foul scripts, I offer no prayer to prevent the

nium. Hawkins 2014: 218 observes that the Stoic's "Hipponactean display throws the onus of connecting the dots onto the audience."

$81 \quad$ Gerber 1999.

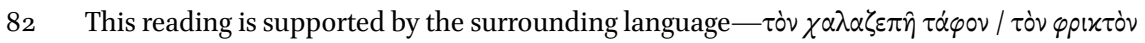
I $\pi \pi \dot{\omega} \nu \alpha \chi \tau \circ \varsigma$, ô $\tau \varepsilon \chi \dot{\alpha} \tau \varepsilon \dot{\varepsilon} \varphi \rho \alpha / i \alpha \mu \beta ı \dot{\alpha} \zeta \varepsilon l(1-3)$-in which the adjective $\chi \alpha \lambda \alpha \zeta \varepsilon \pi \hat{\eta}$ ("hurling abuse as thick as hail" LSJ), together with the proliferation of aspirated sounds, recreates the texture of Hipponactean shivering, casting the tomb, and the iambic tradition, as an archive of shudders. 
chill from bringing a head cold and cough not to me, but to Sestius himself, since he invites me only when I have read a baneful book.

Brent Vine has recognized in ferat frigus at the end of line 20 "a faint but clear lexical and metrical echo of the mot clén 83 of Hipponax's shivering addresses to Hermes, which, as we have seen, present lines closing with ṕr $\gamma \varepsilon \circ \varsigma$ and $\dot{p} 1 \gamma \hat{\omega}$, cognates with frigus. In triggering the rhythmical breach distinctive of the choliamb, frigus like tussis bodies forth the cough that provides the poem's generative conceit. Although cough and chills are said to have been caused by the frigid orator Sestius' speech "full of venenum," this narrative may playfully cover up the real culprit - the venomous Hipponax. The lyric influence of Hipponax, whose beggarly persona is already reflected in Catullus' selfpresentation as a parasite enslaved to his belly (venter, 8 ), may have made Catullus catch a cold, realizing the threat raised by Hipponax's $\varphi p(x \tau$ ós tomb, an archive of shivers. The appropriation of a generic form, then, has physiological consequences. $^{84}$ The feel of iambos is passed on to Catullus' readers through tussis, used three times in a final trochee (the rhythmical cough); 85 the rhotic, fricative, and guttural sounds that rework and extend the Hipponactean tag ferat frigus (gravedo/gravedinem, frigida, frequens); ${ }^{86}$ and quassavit. The last

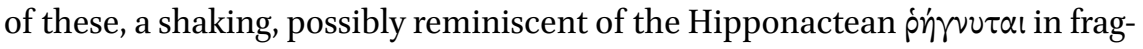
ment 34, translates the shiver roughening Hipponax's skin into fractured syntax, the sharp enjambment that separates the verb in line 14 from the subject tussis (possibly etymologically connected with tundo, "thrust, knock"). ${ }^{87}$ Allied with the salubrious fundus - the poem's Hermes-like addressee - the remedy for Catullus' illness, "nettle" (urtica), equally contributes to this materialization of generic sensation. Like Hipponax's $\delta \alpha \sigma \varepsilon \hat{i} \alpha \lambda \lambda \alpha \hat{\imath} \nu \alpha$, the urtica exemplifies the duplicity of a pápraxov (or, the Latin equivalent, venenum) as both drug and

83 Vine 2009: 215 .

84 Young 2015b: 116-120 has viewed Catullus' translation of Sapph. fr. $3^{1} \mathrm{~V}$ in poem $5^{1}$ as a "virulently contagious" experience whereby the Roman poet "allow[s] the form of erotic selfhood [Sappho] modeled to seep under his skin and into his own poem." In poem 36 Catullus uses the phrase truces vibrare iambos (5), which is usually taken as an allusion to the possible derivation of $i \alpha \mu \beta$ os from $i \alpha \dot{\alpha} \tau \varepsilon i v$. One may also see a subliminal reference to the bodily vibrations, the horrores produced by the genre.

85 In line 7 , as well as lines 13 and 19.

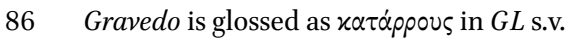

87 In Sen. Ep. 95.17 fevers are described as accompanied "by much shaking (quassatione) of limbs." In English, the phoneme $q u$ - has been judged a phonestheme of the idea of "shaking" (quake, quiver, quaver, quash): see Marchand 1959: 258. The iterative verb quassavit could also render $\beta \alpha \mu \beta \alpha \lambda \dot{\zeta} \zeta \omega$ in fr. 32 , where the reduplication $(\beta \alpha \mu \beta \alpha-)$ onomatopoetically expresses the continuous movement of chattering teeth. 
poison-delivering therapeutically burning stings that, along with the shivers themselves, channel iambic affect. ${ }^{88}$ Sensually akin to the hedgehog, the nettle belongs among Hipponax's prickly flora. Indeed, the appearance of urtica in the same marked metrical position as frigus and tussis underscores this collapsing of remedy and illness, which may potentially turn the wholesome fundus into a Hipponactean thorny garden, if we consider the medicinal plant, as much as the otium, a product of the farm. We can see something similar in the proximity of refectus (preceded by quare) and recuravi $\left(1^{-16}\right)$, which, through the repetition of $r$, emphasize recovery while diffusing a rhotic sensation (cf. frequens tussis 13) that perhaps evocatively reaches back to the Hipponactean ṕr $\gamma v v \tau \alpha$. At the formal level, it is through sound that the vitality of Catullus' ostensibly cured illness lingers and remains transmissible to other victims (Sestius as well as listeners/readers). There is, in a sense, a homology between the sounds and the urtica, which, in its own way, keeps the illness alive, redoubling it by applying an iambic sting to iambic chills. The correspondence between urtica and frigus, burning remedy and chilly illness, in turn, invites us to consider a further aspect of aesthetic duplicity. Not only can the curative pharmakon act as a prickly venom, but shivers, pungent sensations, bodily lacerations, and aspirated intensities can themselves be thought of as healing, a cleansing through and as pain that would cast iambos' feel—its "attractive aversion[s]"89—as a quasi-cathartic force.

Hipponax's shaggy $\chi \lambda \alpha i v \alpha$ and Catullus' urtica, which roughens his villa's comforting (and seductive) bosom (in tuum sinum 14), ${ }^{90}$ are emblematic of iambos' masochistic asperity, the way this genre projects the painful pleasures of edgy experiences. The iambographer's request for bodily protection in the form of an "aspirated" textile reinscribes pain within pleasure. As shown by the outburst of aspirated sounds-materializations of somatic horror on the page-it also feels theatrically insincere, a masochist's disingenuous plea to end the game. If the iambographer's own chilly shudders ceased reverberating on the reader, the poem would be depleted of its generic vitality. Coldness, which, as we have seen, is central to the iambic imaginary (of Hipponax as well as Archilochus) and to the symbolism of $r h o / r$, is the feeling of social exclusion, bringing pockets of death into our bodies. ${ }^{91}$ This impulse may underlie the

88 The presence of recuravi and urtica in the same line (15) makes us see in the former's phonetic configuration the latter's burning force, captured by its etymological link with uro.

89 I borrow this phrase from Korsmeyer 2011.

9o In line 17 es ulta signals a shift of address from the fundus to the villa (see Fordyce 1961: 201), eroticized by in tuum sinum fugi (14).

91 See Clare 2013: 176: "[Coldness] is the bit of death inside of me that I struggle to guard 
pushing of aesthetic boundaries fostered by the imaginary contact with iambic surfaces-brambles and wood, Thasos' craggy landscape, bushy or spiny animals, frigid temperatures. At the same time, since the iambographer is always positioned on the line between attacker and victim, sadistic and masochistic impulses, the audience's absorption of the sensations he generates and ostensibly feels may result in something comparable to the Freudian notion of reflexive masochism. Such a notion is predicated on "two contrary images of self - the image of the one who pleasurably inflicts pain ... and that of the one who pleasurably suffers that pain." ${ }^{\text {92 }}$ Kaja Silverman has seen this dynamic at work in T.E. Lawrence's Seven Pillars of Wisdom, an account of his experience as a member of the British Forces of North Africa during the Arab revolt of 19161918. In this book, physical pain often feels like eroticized pleasure, one that "is compatible with —indeed, perhaps a requisite for—extreme virility" ${ }^{\prime 3} \mathrm{~A}$ sharp crust of snow that gashes wrists and ankles until they bleed, "harsh stalks of wormwood stabbing into wounded" feet, skin torn away in "ragged sheets" by burning rocks, a body kicked by nailed boots, and genitals exposed to "the full length of [the] whip";94 these images, which recall the spiky surfaces of iambos' generic imaginary (brambles and wood, craggy landscapes, frigid temperatures), articulate a corporeal model of subjectivity, whereby sexually charged physical pain, enervating flagellation, paradoxically entails a self-aggrandizing sense of dominance, "the illusion of a contained and autonomous self." ${ }^{\prime 95}$ This notion is captured in the feel of the R.A.F. uniform, described by Lawrence in another novel- "tightly ... [gripping] the flesh," causing a form of sexual pleasure while impounding and constricting. ${ }^{96} \mathrm{~A}$ similar dynamic lurks behind Hipponax's request for a $\chi \lambda \alpha i v \alpha$ whose scratchiness, in this case, subjects the iambicist to a kind of self-inflicted, perhaps self-fortifying, discomfort. ${ }^{97}$

myself from." Deleuze 1991: 52 sees coldness as the programmatic antisensual, frozen condition of the masochist, who, although he feels, is constantly engaged in "the disavowal of sensuality." The characters we see in Leopold Von Sacher-Masoch's Venus in Furs are frequently cold, especially the women, "so chilled that they must be wrapped in furs and set before the fire" (MacKendrick 1999: 59).

92 Silverman 1992: 325. Reflexive masochism is elaborated by Freud 1915, who sees it as a defense against the castrating power of so-called feminine masochism.

93 Silverman 1992: 327. In a fable preserved by Babrius (95.74) but probably containing much older Aesopic material, a fox — an emblem of iambic bristliness, as we have seen — blames a deer for not being able to "endure the scratch" of a lion's paw: see Kurke 2011: 154-155.

94 Lawrence 1962: 509, 454, 487, 308.

95 Silverman 1992: 326.

96 Lawrence 1955: 56 .

97 Iambos' generic imaginary includes other hints of masochism. In Pythian 2, which polemically engages with Archilochus (see esp. Brown 2006), Pindar refers to abusers, probably 
An alternative to this paradigm - equally suitable to iambos' sympotic male homosociality, but conceivable for other readerly contexts across time, space, and gender-is Leo Bersani's idea of "sexuality as productive masochism." 98 Programmatically contesting the ideal of the unified self, the masochistic "selfshattering" that Bersani sees as intrinsic to the experience of sexuality could exemplify an equation between "self-divestiture" and "self-expansiveness, ... something like ego-dissemination rather than ego-annihilation." "Shatter-

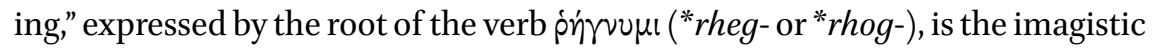
domain that connects iambos' form, its distinctive sounds and rhythm, with its vision of a body exposed to "sadomasochistic thrills" - a vision not altogether different from the representation of love travails in Sappho fragment 31, where the body trembles and the tongue is splintered. ${ }^{100}$ An extreme variant of the

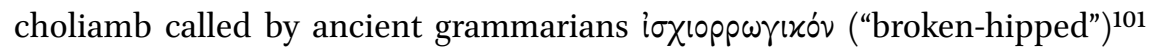
seems a metrical expression of the shivering Hipponax's chillblain-wracked

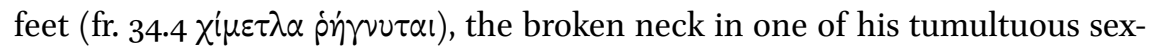

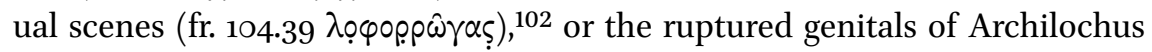
himself or of one of his targets (fr. $252 \dot{\alpha} \lambda \lambda^{\prime} \dot{\alpha} \pi \varepsilon p \rho \omega^{\prime} \gamma \alpha \sigma \iota \mu v^{\prime} x \varepsilon \omega \tau \varepsilon^{\prime} v 0 v \tau \varepsilon \varsigma$ ). In these shattered corporealities we can perceive, as disabilities studies have shown us, the potential for an expansive disruption, that is to say, the possibility of an

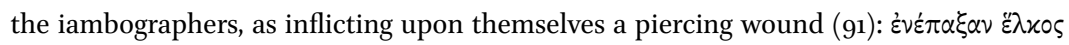

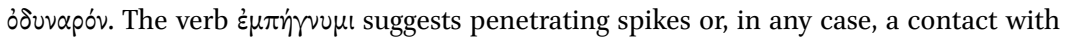
the pointed surfaces we have examined above. In fr. 193, Archilochus presents himself as "pierced $(\pi \varepsilon \pi \alpha \rho \mu \varepsilon$ vo $)$ in his bones" by longing.

98 Bersani 1986: 63 .

99 Bersani and Phillips 2008: 57. The notion of "self-shattering" is discussed in Bersani's famous essay "Is the Rectum a Grave?" (Bersani 20o9: 3-30). For a feminist critique of the notion of "productive masochism," see Booth 2014.

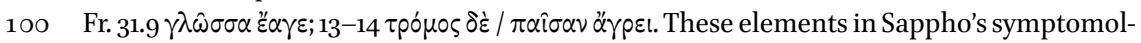
ogy are discussed at length by Bonanno 1993, O'Higgins 199o, and esp. Prins 1999: 27-51. On the poem as a whole, see esp. Carson 1998: 12-17. Cf. also fr. 47 for the image of Eros as a shaking force $(\dot{\varepsilon} \tau i \nu \alpha \xi \xi)$. On iambos and soft lyric genres, see n. 3 .

101 The extant Hipponactean corpus presents thirteen certain examples of this version of the meter, marked by the presence of five long syllables from the fourth foot to the end. If the usual version of the choliamb displays "formlessness and incapacity" (Payne 2010: 38 ), the ischiorrhogic pushes further in the direction of self-imposed disability (and selfovercoming).

102 In the same poem (104W $=107$ Deg.), we find ]pp $\eta^{\circ} \sigma \sigma \omega \nu$ (line 7), most likely a form of $p \dot{\eta} \sigma \sigma \omega$, cognate with $p \dot{\eta} \gamma v v \mu l$; in the following line, we read, in the same metrical position, $\left.\eta_{\rho}\right] \alpha \xi \varepsilon$, probably a form of $\dot{\xi} \xi \alpha \rho \dot{\alpha} \sigma \sigma \omega$, the verb that indicates "shattering" in fragment 22 . We thus find a metrically recursive concentration of $r$ sounds to represent bodily roughness (the

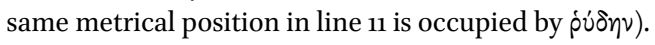


enhanced notion of embodiment, ${ }^{103}$ the idea of "a body ... that opens itself up rather than seals itself"104 or "attempts to escape from itself," in Deleuze's theorization of the spasm. ${ }^{105}$ This self-divestiture is the physical counterpart of the formal trespassing that defines iambos, with its constant projection toward a "you," its inbuilt temptation to break the frame. The rho itself, the sound that,

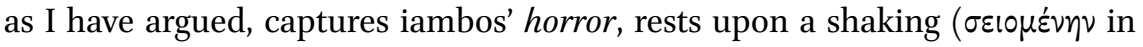
Plato's account), a breaking of vocal bounds, that results in enhancement or, we might say, phonic prosthesis. ${ }^{106}$ Appreciating its programmatic force, heeding its masochistic texture, we can sense iambos' generic affect - a "remapping and reintensifying"107 of feeling itself through the obtrusion of piercing pleasures that break through the fourth wall of the performance and the page of the text.

103 See esp. Braidotti 2013: 146 and Goodley et al. 2014: 348, who observe that "disability crips what it means to be a human being ... [calling] for new ... ways of relating, living, and dying." In this perspective, disability is central to theorizations of human enhancement.

104 The citation is from Grosz 1994: 201.

105 Deleuze 2003: 16, analyzing the spasms represented in Francis Bacon's work as an "approximation of horror or abjection," where "the body exerts itself ... or waits to escape from itself."

106 In Archil. fr. 128 we find the first occurrence in Greek literature of the term $\dot{\rho} v \sigma \dot{\alpha}^{\prime} \varsigma$, referring to the vicissitudes of human life. According to Benveniste 1971: 285-286, the pre-Platonic use of this term exhibits a tension between the etymological meaning- "flowing"-and the idea of a fixed, regular, patterned form, which still permeates contemporary accounts

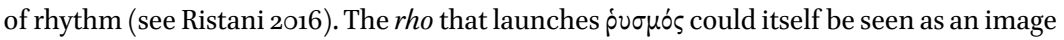
of the body in flux.

107 I borrow this phrase from Sweetman 1999: 179, who considers the expansion of bodily faculties afforded by piercing and tattooing. 